Special issue of the 3rd International Conference on Computational and Experimental Science and Engineering (ICCESEN 2016)

\title{
The Healing Effect of Cimin Grape Against Toxic Effects of $\mathrm{ZnOTiO}_{2}$ Nanocomposite
}

\author{
T. $\operatorname{Atici}^{a}$ And D. Altun ÇOLAK ${ }^{b, *}$ \\ ${ }^{a}$ Erzincan University, Institue of Natural and Applied Science, Erzincan, Turkey \\ ${ }^{b}$ Erzincan University, Faculty of Arts and Sciences, Department of Biology, Erzincan, Turkey
}

Today, occurrence of nanotechnology is making life easier, increasing the individual happiness and attracts attention to the benefits to be provided by it. As with any technology, nanotechnology also has risks, which are discussed here. In this study, toxic effects of $\mathrm{ZnOTiO}_{2}$ nanocomposite on various growth parameters of Drosophila melanogaster and removal of these effects by Cimin grape (Vitis vinifera L. ssp., Cimin) were investigated. For this purpose, assessment of the number of offspring and the survival rate were performed by feeding flies with $\mathrm{ZnOTiO}_{2}$ $(1 \mathrm{mg} / \mathrm{ml})$ and Cimin grape seed and fruit extracts $(5$ and $10 \mathrm{mg} / \mathrm{ml})$. In the first stage, larvae of the the same age were put into the medium of each application group and the adult individuals were recorded. In the second stage, in order to determine the number of offspring in all treatment groups, in a set of experiments the grape extracts and $\mathrm{ZnOTiO}_{2}$ were only applied to the female members, while in another set of experiments, the grape extracts and $\mathrm{ZnOTiO}_{2}$ were applied only to male members, belonging to the same application group. The total number of flies developed from the eggs laid during ten days of pair mating was counted. As a result, survival rate and the offspring number in the application groups, that were only exposed to $\mathrm{ZnOTiO}_{2}$ were found to show a decline, compared with the other groups. At the same time, the values obtained from the groups, exposed to the $\mathrm{ZnOTiO}_{2}$ and grape extracts together, were close to control group values. This result supports the healing effects of Cimin grape, which is abundant in Erzincan.

DOI: 10.12693/APhysPolA.132.919

PACS/topics: $\mathrm{ZnOTiO}_{2}$, Drosophila melanogaster, Cimin Grape, Survival Rate, Offspring Number

\section{Introduction}

A dramatic increase in the use of nanoparticles (NPs) in a variety of applications has raised concerns about the impacts of them on health and the environment [1]. The in vitro and in vivo studies, using different experimental models indicate that nanoparticles may cause genotoxic and cytotoxic effects, that involve oxidative stress and inflammation [2-4]. Titanium dioxide $\left(\mathrm{TiO}_{2}\right)$ and zinc oxide ( $\mathrm{ZnO}) \mathrm{NPs}$, which are especially used in food products, drugs, cosmetics and sunscreens, are of special concern, because they are two of the fastest growing product categories in the nanotechnology [5].

Drosophila melanogaster is the most used nonmammalian model species for human health nanotoxicology research and for biomedical research, with numerous advantages over other vertebrate species $[6,7]$. Thus, in our study we investigated protective role of Cimin grape (CG) - a single standard grape variety of Erzincan, Üzümlü - seed and fruit extracts against possible toxic effects of $\mathrm{ZnOTiO}_{2}$ nanocomposite on some developmental parameters of Drosophila melanogaster.

\section{Materials and methods}

\subsection{Strains}

The Oregon R wild type (w.t.) strain of Drosophila melanogaster larvae and adults (Diptera; Drosophilidae)

\footnotetext{
*corresponding author; e-mail: dnz_altun@yahoo.com
}

were used in experiments. The flies were kept at a constant temperature of $25 \pm 1{ }^{\circ} \mathrm{C}$ and in darkness, on a standard medium, composed of maize flour, agar, sugar, dried yeast and propionic acid (Standart Drosophila Medium, SDM). The humidity of the experimental chamber was $40-60 \%$.

\subsection{Experimental procedures}

For survival rate experiments, a hundred larvae of the same age (72 hours) were transferred to control and application culture media, containing different concentrations of Cimin grape seed and fruit extracts ( 5 and $10 \mathrm{mg} / \mathrm{ml}$ ) and $\mathrm{ZnOTiO}_{2}(1 \mathrm{mg} / \mathrm{ml})$. During seven days, the individuals that could develop from larvae to adults were recorded.

In order to determine the number of offspring in all applied groups, in a set of experiments, $\mathrm{ZnOTiO}_{2}$ and the grape seed and fruit extracts were applied to the female members (males were fed only in SDM), while in the another set of experiments $\mathrm{ZnOTiO}_{2}$ and the grape seed and fruit extracts were applied to male members (females were fed only in SDM). Exposed individuals and unexposed individuals have mated in SDM. Offspring numbers in $\mathrm{F}_{1}$ progeny, developed from the eggs laid during these ten days of pair mating, were counted. The obtained data was analysed with SPSS version 15.0 (Statistical Package for the Social Sciences Software, SPSS, Chicago, IL).

\section{Results}

It has been observed that $\mathrm{ZnOTiO}_{2} \mathrm{NPs}_{\mathrm{s}}$, applied to larvae, have decreased the survival rate, according to control group, and Cimin grape seed and fruit extracts have 
increased the survival rate (Table I and Fig. 1). Fruit flies in Cimin grape seed extract $(10 \mathrm{mg} / \mathrm{ml})$ application group had the largest survival rate and the application group, fed with $\mathrm{ZnOTiO}_{2}(1 \mathrm{mg} / \mathrm{ml})$ had the smallest survival rate.

TABLE I

The effects of $\mathrm{CG}$ against $\mathrm{ZnOTiO}_{2}$ on survival rate of $D$. melanogaster.

\begin{tabular}{|c|c|c|c|c|}
\hline & \multirow[b]{2}{*}{ Concentration } & \multicolumn{3}{|c|}{ The mean survival rate \pm standard error } \\
\hline & & $\begin{array}{c}\text { Male } \\
\text { population }\end{array}$ & $\begin{array}{c}\text { Female } \\
\text { population }\end{array}$ & $\begin{array}{c}\text { Total } \\
\text { population }\end{array}$ \\
\hline & Control & $40 \pm 1.52^{\mathrm{d}}$ & $32 \pm 1.15^{\mathrm{c}}$ & $72 \pm 1.73^{\mathrm{e}}$ \\
\hline & $1 \mathrm{mg} / \mathrm{ml} \mathrm{ZnOTiO}_{2}$ & $18 \pm 1.52^{\mathrm{a}}$ & $17 \pm 1.00^{\mathrm{a}}$ & $35 \pm 2.08^{\mathrm{a}}$ \\
\hline \multirow{4}{*}{$\mathrm{CG}$} & $\mathrm{SE} 5 \mathrm{mg} / \mathrm{ml}$ & $45 \pm 1.52^{\mathrm{ef}}$ & $38 \pm 1.15^{\mathrm{d}}$ & $83 \pm 2.08^{g}$ \\
\hline & $\mathrm{FE} 5 \mathrm{mg} / \mathrm{ml}$ & $38 \pm 1.52^{\mathrm{d}}$ & $36 \pm 1.52^{\mathrm{cd}}$ & $74 \pm 2.00^{\mathrm{ef}}$ \\
\hline & $\mathrm{SE} 10 \mathrm{mg} / \mathrm{ml}$ & $47 \pm 1.52^{\mathrm{f}}$ & $42 \pm 1.15^{\mathrm{e}}$ & $89 \pm 1.00^{\mathrm{h}}$ \\
\hline & $\mathrm{FE} 10 \mathrm{mg} / \mathrm{ml}$ & $42 \pm 2.08^{\mathrm{de}}$ & $36 \pm 1.15^{\mathrm{cd}}$ & $78 \pm 1.00^{\mathrm{fg}}$ \\
\hline \multirow{4}{*}{$\begin{array}{c}\mathrm{CG}+ \\
\mathrm{ZnOTiO}_{2}\end{array}$} & $\mathrm{SE} 5 \mathrm{mg} / \mathrm{ml}+1 \mathrm{mg} / \mathrm{ml}$ & $25 \pm 1.15^{\mathrm{b}}$ & $24 \pm 1.52^{\mathrm{b}}$ & $49 \pm 1.73^{\mathrm{c}}$ \\
\hline & $\mathrm{FE} 5 \mathrm{mg} / \mathrm{ml}+1 \mathrm{mg} / \mathrm{ml}$ & $22 \pm 1.52^{\mathrm{ab}}$ & $18 \pm 1.52^{\mathrm{a}}$ & $40 \pm 2.00^{\mathrm{ab}}$ \\
\hline & $\mathrm{SE} 10 \mathrm{mg} / \mathrm{ml}+1 \mathrm{mg} / \mathrm{ml}$ & $30 \pm 1.73^{\mathrm{c}}$ & $26 \pm 1.15^{\mathrm{b}}$ & $56 \pm 2.88^{\mathrm{d}}$ \\
\hline & $\mathrm{FE} 10 \mathrm{mg} / \mathrm{ml}+1 \mathrm{mg} / \mathrm{ml}$ & $24 \pm 1.73^{\mathrm{b}}$ & $20 \pm 1.52^{\mathrm{a}}$ & $44 \pm 2.08^{\mathrm{bc}}$ \\
\hline
\end{tabular}

${ }^{a-h}$ : The letters in the same column show a significant difference at $5 \%$ level.

In F1 progeny, resulted from seed and fruit extracts and $\mathrm{ZnOTiO}_{2}$ application to male and female individuals, $\mathrm{ZnOTiO}_{2}$ has caused a decrease in the number of younger individuals. On the other hand, CG seed and fruit extracts have increased the number of younger in- dividuals (Table II and Fig. 2). These differences, which are observed in the survival rate and the offspring number values for control group, are significant statistically at a level of $p<0.05$.

TABLE II

The effects of CG against $\mathrm{ZnOTiO}_{2}$ on offspring number of D. melanogaster.

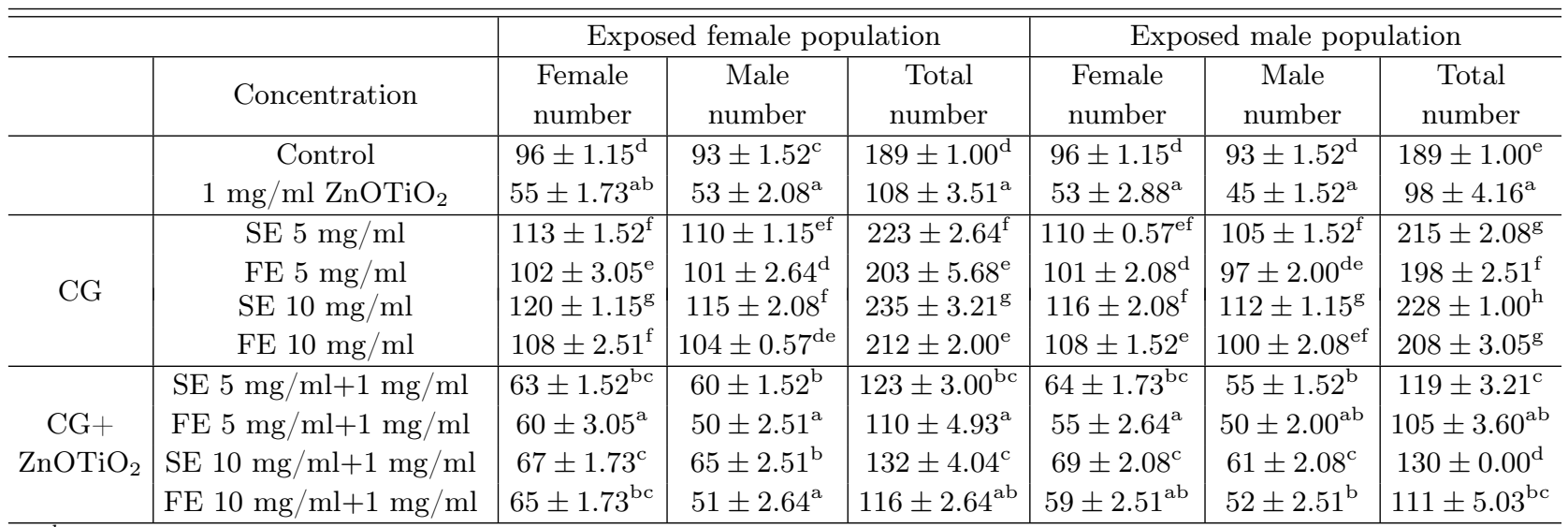

${ }^{a-h}$ : The letters in the same column show significant difference at $5 \%$ level.

\section{Discussion}

Nano-bio interference can result in detrimental biological effects like generation of reactive oxidative species
(ROS), cytotoxicity, genotoxicity and inflammatory responses $[8,9]$. In recent years, the number of studies about the toxic risks of NPs is increasing [10]. The data 


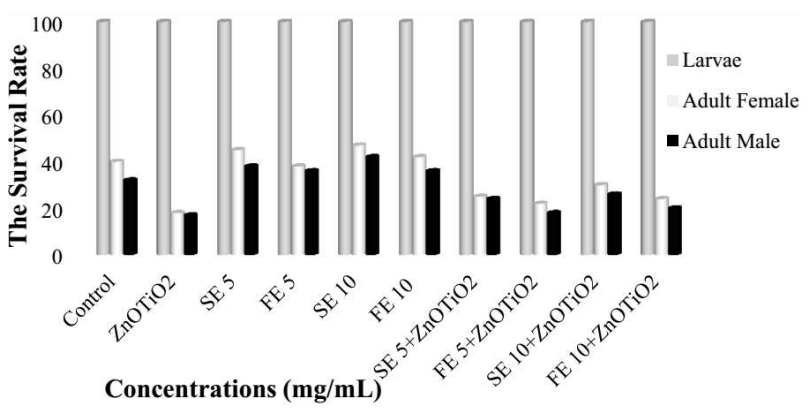

Fig. 1. The effects of $\mathrm{CG}$ against $\mathrm{ZnOTiO}_{2}$ on survival rate of $D$. melanogaster.

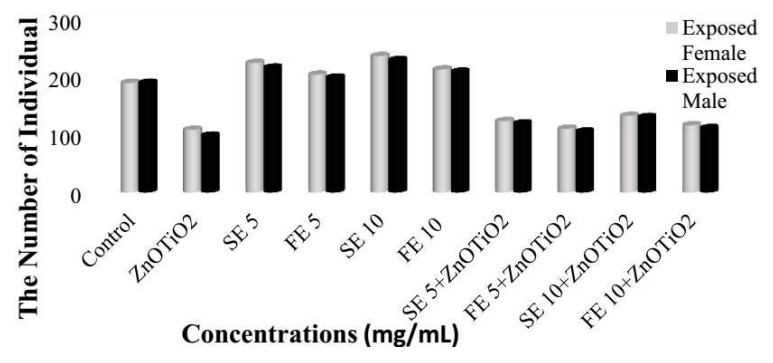

Fig. 2. The effects of $\mathrm{CG}$ against $\mathrm{ZnOTiO}_{2}$ on offspring number of $D$. melanogaster.

from several in vitro studies have demonstrated that $\mathrm{TiO}_{2}$ NPs cause various adverse effects at the cellular level, such as oxidative stress and DNA damage [11]. In vivo toxicity studies have demonstrated that inhalation of $\mathrm{TiO}_{2}$ NPs induce DNA damage and genetic instability in mice [12]. Similarly, it is shown that $\mathrm{TiO}_{2}$ NPs were capable of causing genotoxicity by inducing oxidative DNA damage, sister chromatid exchange and micronucleus formation in human white blood cells and human bronchial epithelial cells $[13,14]$.

In addition, in vivo and in vitro studies of $\mathrm{ZnO} N \mathrm{NP}$ have reported them to be toxic. ZnO NPs have been shown to induce morphological modifications, oxidative stress, lipid peroxidation, mitochondrial dysfunction, cytotoxicity, chromosomal breakage and micronuclei formation [15-17]. In a study, third instar larvae haemocytes were used to evaluate the effect of NPs on oxidative stress. Increased oxidative load with increasing concentration of ZnO NPs clearly indicates towards oxidative stress triggered by these NPs. In addition, this study has clearly shown that ZnO NPs cause phenotypic abnormalities, which might be transmitted to the progeny, while no phenotypic abnormality was reported in parent flies [18]. The genotoxic potential of ZnO NPs has been demonstrated in ovary cells of Chinese hamsters, by chromosome aberration test [19], in a human epidermal cell line [20], in primary human epidermal keratinocytes [21] and in human liver cells [22] by comet assay and in the human carcinoma cell line by comet and micronucleus assays [23].

Many reports indicate that antioxidants, especially fruit and vegetables, contribute significantly to prevention of oxidative stress. This paper summarizes the evidence supporting the potentially beneficial effects of Cimin grape. Although the mechanism by which polyphenols prevent oxidative stress is still not clear, a daily supplementation of Cimin grape seems to be a good strategy to inhibit the free radicals.

\section{References}

[1] T. Xia, N. Li, A.E. Nel, Ann. Rev. Publ. Health 30, 137 (2009).

[2] J. Petković, B. Žegura, M. Stevanović, N. Drnovšek, D. Uskoković, S. Novak, M. Filipić, Nanotoxicology 5, 341 (2011).

[3] K.E. Driscoll, L.C. Deyo, J.M. Carter, B.W. Howard, D.G. Hassenbein, T.A. Bertram, Carcinogenesis 18, 423 (1997).

[4] B. Trouiller, R. Reliene, A. Westbrook, P. Solaimani, R.H. Schiestl, Cancer Res. 69, 8784 (2009).

[5] Y. Ju-Nam, J.R. Lead, Sci. Total Environ. 400, 396 (2008).

[6] B.H. Jennings, Materials Today 14, 190 (2011).

[7] G. Vecchio, Nanotoxicology 9, 135 (2015).

[8] K. Klien, J. Godnic-Cvar, Arch. Industrial Hygiene Toxicol. 63, 133 (2012).

[9] S.J. Soenen, P. Rivera-Gil, J.-M. Montenegro, W.J. Parak, S.C. De Smedt, K. Braeckmans, Nano Today 6, 446 (2011).

[10] R. Landsiedel, M.D. Kapp, M. Schulz, K. Wiench, F. Oesch, Mutation Res. 681, 241 (2009).

[11] J.J. Wang, B.J. Sanderson, H. Wang, Mutation Res. 628, 99 (2007).

[12] B. Trouiller, R. Reliene, A. Westbrook, P. Solaimani, R.H. Schiesti, Cancer Res. 69, 8784 (2009).

[13] H. Türkez, F. Geyikoğlu, Toxicol. Industrial Health 23, 19 (2007).

[14] J.R. Gurr, A.S. Wang, C.H. Chen, K.Y. Jan, Toxicology 213, 66 (2005).

[15] M. Horie, K. Nishio, K. Fujita, S. Endoh, A. Miyauchi, Y. Saito, H. Iwahashi, K. Yamamoto, H. Murayama, H. Nakano, N. Nanashima, E. Niki, Y. Yoshida, Chem. Res. Toxicol. 22, 543 (2009).

[16] R. Guan, T. Kang, F. Lu, Z. Zhang, H. Shen, M. Liu, Nanoscale Res. Lett. 7, 602 (2012).

[17] V. Valdiglesias, C. Costa, G. Kilic, S. Costa, E. Pásaro, B. Laffon, J.P. Teixeira, Environm. Int. 55, 92 (2013).

[18] A.S. Anand, D.N. Prasad, S.B. Singh, E. Kohli, J. Hazardous Mater. 327, 180 (2017).

[19] E.K. Dufour, T. Kumaravel, G.J. Nohynek, D. Kirkland, H. Toutain, Mutation Res. 607, 215 (2006).

[20] V. Sharma, R.K. Shukla, N. Saxena, D. Parmar, M. Das, A. Dhawan, Toxicol. Lett. 185, 211 (2009).

[21] V. Sharma, S.K. Singh, D. Anderson, D.J. Tobin, A. Dhawan, J. Nanosci. Nanotechnol. 11, 3782 (2011).

[22] V. Sharma, D. Anderson, A. Dhawan, J. Biomed. Nanotechnol. 7, 98 (2011).

[23] I.F. Osman, A. Baumgartner, E. Cemeli, J.N. Fletcher, D. Anderson, Nanomedicine-UK 5, 1193 (2010). 